\title{
Multiple Heliconia Genotypes under 50 Per Cent Shadehouse Conditions: Physiological and Biochemical Responses
}

\author{
M. Dilipkumar Naik ${ }^{1 *}$, M. Raja Naik ${ }^{1}$, M. Ramakrishna ${ }^{1}$, K. Lalitha ${ }^{1}$, \\ K. Arunodhayam ${ }^{1}$ and Y. Sharat Kumar Reddy ${ }^{2}$
}

${ }^{1}$ College of Horticulture (Dr. Y.S.R.H.U), Anantharajupeta - 516 105, Y.S.R Kadapa Dist. Andhra Pradesh, India

${ }^{2}$ Horticulture Research Station (Dr. Y.S.R.H.U), Anantharajupeta - 516 105, Y.S.R Kadapa Dist. Andhra Pradesh, India

*Corresponding author

A B S T R A C T

\begin{tabular}{|l|}
\hline Ke y w or d s \\
Heliconia genotypes, \\
Physiological, \\
Biochemical \\
attributes, Shadehouse \\
condition, \\
Performance to the \\
region
\end{tabular}

The present investigation was carried out at College of Horticulture, Anantharajupeta during 2018-19. The experiment was laid out in Randomized Block Design, with three replications and with 8 genotypes. The treated rhizomes were planted under 50 per cent shadehouse condition. All the physiological attributes and anthocyanin content varied significantly among multiple heliconia genotypes studied under shadehouse conditions. Among different genotypes tried, leaf area $\left(814.57 \mathrm{~cm}^{2}\right)$, SPAD (SCMR) value for chlorophyll content $(65.62)$, stomatal conductance $\left(0.38 \mathrm{~mol} \mathrm{~m}^{-2}\right.$ $\left.\mathrm{s}^{-1}\right)$, rate of photosynthesis $\left(9.23 \mu \mathrm{mol} \mathrm{m} \mathrm{m}^{-2} \mathrm{~s}^{-1}\right)$, transpiration rate $(4.17$ mmol m$~^{-2} \mathrm{~s}^{-1}$ ) and anthocyanin content in flowers (3.64 $\mathrm{mg} 100 \mathrm{~g}^{-1}$ tissue) recorded were highest in genotype $\mathrm{G}_{6}$. Significantly more leaf intercellular $\mathrm{CO}_{2}\left(317.38 \mu \mathrm{mol} \mathrm{m} \mathrm{m}^{-2} \mathrm{~s}^{-1}\right)$ and leaf temperature $\left(34.30{ }^{0} \mathrm{C}\right)$, respectively was recorded in genotype $G_{3}$. While the genotype $G_{5}$ had maximum number of stomata $\left(45.80 \mathrm{~mm}^{2}\right)$.

\section{Introduction}

Heliconia, is a rhizomatous, herbaceous perennial plant and commonly known as 'Lobster-claws', 'Wild plantains' or 'False bird of paradise'. Heliconia (Heliconia spp.) belongs to family Heliconiaceae and is amongst the most attractive of all the exotic tropical flowering plants, comprises of single genus, with about 250-300 species. Heliconias are native to Central and South America, the Caribbean Islands and some of the islands of South Pacific, possessing chromosome number $2 \mathrm{n}=24$. It is distributed primarily from the North of Mexico to the South of Brazil. Some species of heliconia are utilized as ornamental plants, usually being grown both as landscaping plant and as cut flowers owing 
to its colour and longer durability of its floral bracts. Wide variation in vegetative growth, size, shape and arrangement of bracts has been reported by different authors (Kokila et al., 2016). Due to its unusual inflorescence, heliconia is categorized as 'Specialty Flower' (Malakar et al., 2015).

Colourful bracts protect the small flowers and form the inflorescence, which are used as cut flowers and landscaping featured plants. Heliconia is mostly grown for beautifying the garden, presently growing as cut flower because of its brilliant color, exotic form, long, straight peduncles and excellent postharvest characteristics, tolerance to biotic and abiotic stresses and reasonable prices. These all features made it an outstanding flower for the florist. It likes warm and humid conditions and can grow well even under partial shade (Dalawai et al., 2017).

Now-a-days, research in the field of crop improvement leads to the introduction of different varieties having different forms and colors by both government and private institutions. According to flowering habit, they are grouped in different groups viz., erect growing ones and pendant or hanging type. Though many genotypes of heliconia can be grown in any agro-climatic region, all of them are not suited for cut flower purpose or for garden display or for exhibition purpose. So, there is a need to evaluate hybrids and varieties in any particular agro-climatic region. Anantharajupeta falling in Southern region of Andhra Pradesh is a potential region with rich crop diversity. It is endowed with mild tropical climate and red loamy soils. Several reports of good performance by modern cut flowers are available from the location (Sirisha, 2016). To meet the growing demand for cut flowers in the fast growing areas of Rayalaseema region of Andhra Pradesh, introduction and popularization of modern flowers is necessary.
Present day varieties are available in diverse forms, types and a wide spectrum of colors. At present, the farmers are not aware of the improved varieties and are still growing only local varieties which are not only less attractive in their shape, size and colour, but also exhibit very low productivity. In heliconia, sufficient number of varieties or genotypes is under cultivation but their performance varies from place to place. The quality of cut flower is primarily a varietal trait and is generally influenced by climatic conditions prevailed during the growing period at a particular place. It is very essential to study the performance of varieties in a particular place before recommending to the farmers. Though the crop has great significance in the market, there are some bottlenecks associated in its cultivation. Non availability of planting material, lack of improved varieties, high market fluctuations are some of the other problems which are often faced by the farmers. The results obtained from this study would be a base to develop a strong breeding program for heliconias and to identify the best genotypes suitable for the region. Keeping the above in view, an investigation was planned and carried out.

\section{Materials and Methods}

The present investigation was carried out during the year 2018-2019 at College of Horticulture, Dr. Y.S.R Horticultural University, Anantharajupeta, Y.S.R Kadapa Dist. of Andhra Pradesh. The trial was planned with seven genotypes collected from Horticultural Research Station, Pandirimamidi, East Godavari Dist. (Dr. Y.S.R Horticultural University, Andhra Pradesh) and one genotype is collected from local farmer at Dumpalagattu (village), Khazipet (mandal), Y.S.R Kadapa Dist. Andhra Pradesh. The experiment was laid out in Randomized Block Design, with three 
replications and with 8 genotypes viz., $\mathrm{G}_{1}$ Heliconia cv. Golden Torch, $\mathrm{G}_{2}-$ Heliconia psittacorum rubra, $\mathrm{G}_{3}-$ Heliconia densiflora, $\mathrm{G}_{4}-$ Heliconia cv. Orange By Gyro, $\mathrm{G}_{5}$ Heliconia cv. Alan Carle, $\mathrm{G}_{6}$ - Heliconia rostrata, $\mathrm{G}_{7}-$ Heliconia cv. Eden Pink and $\mathrm{G}_{8}$ - Local check.

Ploughing and digging of the land was done and brought to fine tilth. The plots were prepared under shadehouse condition with 50 per cent shade. All the stubbles of previous crop and weeds were removed from the field and burnt. The required numbers of plots (24) were prepared of size $(4.00 \mathrm{~m} \times 3.20 \mathrm{~m})$. The soil of experimental block was red loamy with pH 7.40 and E.C. $0.27 \mathrm{dSm}^{-1}$. Rhizomes were treated with ridomil $\mathrm{MZ} 1.5 \mathrm{~g}+$ dimethoate 2 $\mathrm{ml}+$ dhanuvit $0.5 \mathrm{ml}$ litre $^{-1}$ water before sowing. The healthy rhizomes were planted into the pits at a depth of $10-15 \mathrm{~cm}$, at a spacing of $1.00 \mathrm{~m} \times 0.80 \mathrm{~m}$ during first week of June, 2018. Rhizome planting was done in the morning hours and light irrigation was given immediately after planting. Organic manure in the form of well rotten farm yard manure was applied @ 1.5-2.0 kg per planting pit prior to rhizome sowing and mixed well. Nitrogen 20g plant ${ }^{-1}$, phosphorus $20 \mathrm{~g} \mathrm{plant}^{-1}$ and potassium 20g plant ${ }^{-1}$ (Dr. Y.S.R.H.U, Andhra Pradesh) were applied monthly prior to blooming. After the commencement of flowering, each clump is applied with nitrogen $10 \mathrm{~g}$ plant $^{-1}$, phosphorus $10 \mathrm{~g}$ plant $^{-1}$ and potassium $20 \mathrm{~g}$ plant $^{-1}$ at monthly intervals. Heliconia genotypes were foliar feeded with potassium nitrate (13:0:45) @ $7 \mathrm{~g} \mathrm{l}^{-1}$ at 6,8 and 10 months after rhizome sowing. Depending upon the weather, soil and crop growth condition, watering was given to heliconia genotypes through drip irrigation at weekly thrice. Necessary plant protection measures were followed to prevent insect pest incidence. Five plants were selected in each plot at random, tagged and labeled properly for recording observations. The experiment was carried out for the period from June, 2018 to May, 2019. The data recorded on various parameters were statistically analyzed by the procedure outlined by (Panse and Sukhatme, 1978).

\section{Results and Discussion}

\section{Leaf area $\left(\mathrm{cm}^{2}\right)$}

Eight heliconia genotypes showed statistically significant difference for leaf area (Table 1). Leaf area recorded was maximum in $\mathrm{G}_{6}$ $\left(814.57 \mathrm{~cm}^{2}\right)$ which was on par with $\mathrm{G}_{7}$ $\left(700.85 \mathrm{~cm}^{2}\right)$ and $\mathrm{G}_{5}\left(606.37 \mathrm{~cm}^{2}\right)$. While the minimum leaf area was recorded in $\mathrm{G}_{2}(67.06$ $\mathrm{cm}^{2}$ ). The variation in the leaf area in different varieties of heliconia may be due to additive gene effect, genetic makeup of the cultivars and the growing conditions. Development of optimal leaf area is important to photosynthesis and dry matter yield. The variation in leaf area might be due to increase in length of leaf, petiole, width of leaf and number of leaves among the different genotypes of heliconia (Dalawai et al., 2017). The parallel results were reported with the studies of Sheela et al., (2007) where maximum leaf area was found in Heliconia bourgena $x$ Heliconia collinsiana cv. 'Pedro Ortiz'.

Similarly, variation in leaf production with different length and breadth might also be due to genetic character of the genotypes. The results of present study confirmed that there is large variation in leaf area within heliconia genotypes and are in line with the conclusions of previous heliconia researchers (Aundhakar, 2008; Kadam et al., 2011). Leaf length and leaf area was significantly different among different cultivars might be due to the genetic variation and difference in adaptation to the agro-climatic condition (Balaram et al., 2009; Pragya et al., 2010; Saleem et al., 2013). Maximum leaf area may lead to more dry 
matter accumulation, which resulted in the accumulation of maximum photosynthates that contributed to produce bigger sized flower or more number of flowers.

\section{Chlorophyll content (SCMR values) in leaves}

Chlorophyll content in leaves was significantly influenced by multiple heliconia genotypes under shadehouse conditions (Table 1). Among the genotypes, the SCMR value recorded was highest (65.62) in $\mathrm{G}_{2}$ which was on par with $\mathrm{G}_{7}$ (64.95) and $\mathrm{G}_{5}$ (61.30), respectively. Lowest SCMR value of 20.62 was recorded in $\mathrm{G}_{3}$. The variation in chlorophyll content of leaf among the genotypes could be attributed to the genetic constitution and varietal character. Increased foliar $\mathrm{N}$ concentration under shade grown plants has been associated with increased leaf chlorophyll concentration, a plant response intended to increase light capture under shaded conditions (de Groot et al., 2002). Wang et al., (2005) demonstrated that the chlorophyll concentration is directly related to the degree of leaf greenness, which represents another important parameter in determining the quality and marketability of the plants at the end of production. Lykas and Katsoulas (2012) also reported that use of shading nets to favour chlorophyll production in compact gardenia (Gardenia jasminoides Ellis.) potted plant. The shade levels of 50 per cent were optimal as a result recorded better chlorophyll content. The shade nets provide the optimal environment for growth of cut greens in subtropical condition both in winter and summer (Gaurav et al., 2015). Chlorophyll content in leaf enhanced photosynthetic activity, which produce carbohydrates. Carbohydrates serve as energy source for growing bud, flower opening and longevity. The ultimate effect of all these factors resulted into strong and long flower stalks, large sized buds or flower (Tarannum and Naik, 2014).

\section{Leaf intercellular $\mathrm{CO}_{2}\left(\mu \mathrm{mol} \mathrm{m} \mathrm{m}^{-2} \mathrm{~s}^{-1}\right)$}

The data corresponding to this trait is presented in Table 2 and significant response was observed among the genotypes. Among multiple genotypes studied for evaluation, the genotype $\mathrm{G}_{3}$ recorded highest leaf intercellular $\mathrm{CO}_{2}\left(317.38 \mu \mathrm{mol} \mathrm{m} \mathrm{m}^{-2} \mathrm{~s}^{-1}\right)$ which was on par with $\mathrm{G}_{4}\left(315.55 \mu \mathrm{mol} \mathrm{m} \mathrm{m}^{-2} \mathrm{~s}^{-1}\right), \mathrm{G}_{6}(315.20$ $\left.\mu \mathrm{mol} \mathrm{m} \mathrm{s}^{-1}\right), \mathrm{G}_{1}\left(312.20 \mu \mathrm{mol} \mathrm{m} \mathrm{s}^{-2}\right), \mathrm{G}_{7}$ $\left(307.87 \mu \mathrm{mol} \mathrm{m} \mathrm{s}^{-1}\right)$ and $\mathrm{G}_{8}\left(300.00 \mu \mathrm{mol} \mathrm{m}{ }^{-2}\right.$ $\left.\mathrm{s}^{-1}\right)$. The lowest value for leaf intercellular $\mathrm{CO}_{2}$ was recorded in $\mathrm{G}_{2}\left(266.50 \mu \mathrm{mol} \mathrm{m} \mathrm{m}^{-2} \mathrm{~s}^{-1}\right)$. The above findings obtained might be due to congenial micro climatic conditions prevail under 50 per cent shade level for the heliconia genotype. This statement find support from Li et al., (2009) they reported that increase in shading increased the leaf intercellular $\mathrm{CO}_{2}$. Among 2 ornamental passion flower hybrids studied, Abreu et al., (2014) recorded higher values for leaf intercellular $\mathrm{CO}_{2}$ in Passiflora 'Aninha' $\left(0.52 \pm 0.29 \mathrm{mmol}\left(\mathrm{H}_{2} \mathrm{O}\right) \mathrm{m}^{-2} \mathrm{~s}^{-1}\right)$, Passiflora 'Priscilla' $\left(0.74 \pm 0.81 \mathrm{mmol}\left(\mathrm{H}_{2} \mathrm{O}\right)\right.$ $\left.\mathrm{m}^{-2} \mathrm{~s}^{-1}\right)$ and in Passiflora palmeri var. sublanceolata $\left(0.74 \pm 0.01 \mathrm{mmol}\left(\mathrm{H}_{2} \mathrm{O}\right) \mathrm{m}^{-2} \mathrm{~s}^{-1}\right)$ among 13 ornamental passion flowers (Pires et al., 2011).

\section{Leaf temperature $\left({ }^{0} \mathrm{C}\right)$}

A critical examination of the data depicted in Table 1 revealed that leaf temperature varied significantly among eight heliconia genotypes grown under shadehouse conditions. Significantly maximum value for the above attribute was observed in $\mathrm{G}_{3}$ which recorded maximum leaf temperature of $34.30{ }^{0} \mathrm{C}$ which was on par with $\mathrm{G}_{7}\left(33.97{ }^{0} \mathrm{C}\right), \mathrm{G}_{2}\left(33.40{ }^{0} \mathrm{C}\right)$, $\mathrm{G}_{4}\left(33.28{ }^{0} \mathrm{C}\right), \mathrm{G}_{5}\left(33.07{ }^{0} \mathrm{C}\right)$ and $\mathrm{G}_{6}(32.55$ $\left.{ }^{0} \mathrm{C}\right)$. The lowest leaf temperature was recorded in $\mathrm{G}_{8}\left(30.84{ }^{\circ} \mathrm{C}\right)$. Thick leaves store more heat than do thin leaves and, consequently, have typically higher leaf temperatures (Lewis and Nobel, 1977). The results suggest, therefore, that different plant genera may depend on 
different processes/traits to effectively regulate the temperature of their leaves and this is also dependent on substrate moisture availability (Gaurav et al., 2015). However, temperature of thin leaves was additionally dependent on leaf color and, in pubescent leaves, the length of leaf hairs (with lighter leaf color and longer hair length being associated with lower temperatures). Conversely, in succulent leaves, temperature was mostly controlled by leaf thickness, with other simultaneously measured factors (such as leaf hairiness and leaf color) not being significant (Gaurav et al., 2015). In contrast, high shade levels reduced leaf temperature (Juan, 2013).

\section{Number of stomata $\left(\mathrm{mm}^{2}\right)$}

The data representing to number of stomata of eight genotypes is furnished in Table 2 and none of the genotypes tried responded significantly to the attribute. However the genotype $\mathrm{G}_{5}$ had highest number of stomata $\left(45.80 \mathrm{~mm}^{2}\right)$. The minimum number of stomata was recorded in $\mathrm{G}_{7}\left(29.60 \mathrm{~mm}^{2}\right)$. It can be linked to the fact that highly pubescent leaves can have a higher number of stomata per leaf area than do glabrous and less pubescent leaves (Skelton et al., 2012). Similar to our results, higher stomatal density has been observed in rose plants (Fanourakis et al., 2013) and in chrysanthemum (Aliniaeifard and Meeteren, 2016).

\section{Stomatal conductance $\left(\mathrm{mol} \mathrm{m}^{-2} \mathrm{~s}^{-1}\right)$}

Analysis of data with respect to stomatal conductance is presented in Table 2. The above parameter shows significant response among 8 genotypes tried under shadehouse conditions. The genotype $\mathrm{G}_{6}$ recorded the maximum stomatal conductance $\left(0.38 \mathrm{~mol} \mathrm{~m}^{-2}\right.$ $\left.\mathrm{s}^{-1}\right)$ which was on par with $\mathrm{G}_{7}\left(0.21 \mathrm{~mol} \mathrm{~m}^{-2} \mathrm{~s}^{-}\right.$ $\left.{ }^{1}\right)$. Higher stomatal conductance in $\mathrm{G}_{6}$ genotype found during current study indicates that this may tend to diffuse more $\mathrm{CO}_{2}$ to chloroplast and thus have greater photosynthetic activity and produce more biomass. Stomatal conductance is a numerical measure of the rate of passage of either water vapour or carbon dioxide through the stomata. Stomatal conductance plays an important role in the plant-atmosphere water exchange and, hence, it is a key parameter in many ecological models (Chen et al., 1999).

Table.1 Physiological traits of different heliconia genotypes under shadehouse conditions

\begin{tabular}{|c|c|c|c|c|c|}
\hline \multicolumn{2}{|c|}{ Genotypes } & \multirow{2}{*}{$\begin{array}{c}\begin{array}{c}\text { Leaf area } \\
\text { plant }^{-1} \\
\left(\mathbf{c m}^{2}\right)\end{array} \\
505.37\end{array}$} & \multirow{2}{*}{$\begin{array}{c}\begin{array}{c}\text { Chlorophyll } \\
\text { content } \\
\text { (SCMR) }\end{array} \\
49.08\end{array}$} & \multirow{2}{*}{ 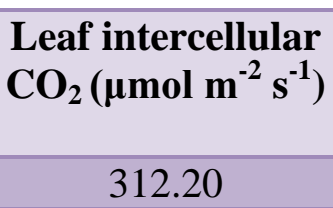 } & \multirow{2}{*}{$\begin{array}{c}\begin{array}{c}\text { Leaf } \\
\text { temperature } \\
\left({ }^{\mathbf{0}} \mathbf{C}\right)\end{array} \\
32.29\end{array}$} \\
\hline $\mathbf{G}_{1}$ & Heliconia cv. Golden Torch & & & & \\
\hline $\mathbf{G}_{\mathbf{2}}$ & Heliconia psittacorum rubra & 67.06 & 34.33 & 266.50 & 33.40 \\
\hline $\mathbf{G}_{3}$ & Heliconia densiflora & 87.40 & 20.62 & 317.38 & 34.30 \\
\hline $\mathbf{G}_{4}$ & $\begin{array}{l}\text { Heliconia cv. Orange By } \\
\text { Gyro }\end{array}$ & 288.61 & 41.43 & 315.55 & 33.28 \\
\hline $\mathbf{G}_{5}$ & Heliconia cv. Alan Carle & 606.37 & 61.30 & 275.32 & 33.07 \\
\hline $\mathbf{G}_{\mathbf{6}}$ & Heliconia rostrata & 814.57 & 65.62 & 315.2 & 32.55 \\
\hline $\mathbf{G}_{7}$ & Heliconia cv. Eden Pink & 700.85 & 64.95 & 307.87 & 33.97 \\
\hline $\mathbf{G}_{8}$ & Local Check & 243.37 & 44.10 & 300.00 & 30.84 \\
\hline & SEM \pm & 76.49 & 5.22 & 8.20 & 0.57 \\
\hline & $\mathrm{CD}(P=0.05)$ & 234.26 & 16.01 & 25.11 & 1.77 \\
\hline
\end{tabular}


Table.2 Physiological and biochemical attributes of different heliconia genotypes under shadehouse conditions

\begin{tabular}{|c|c|c|c|c|c|c|}
\hline \multicolumn{2}{|r|}{ Genotypes } & \multirow{2}{*}{$\begin{array}{c}\begin{array}{c}\text { No. of } \\
\text { stomata } \\
\left(\mathbf{m m}^{\mathbf{2}}\right)\end{array} \\
35.20\end{array}$} & \multirow{2}{*}{$\begin{array}{c}\begin{array}{c}\text { Stomatal } \\
\text { conductance } \\
\left(\mathbf{m o l ~ m}^{-2} \mathbf{s}^{-1}\right)\end{array} \\
0.20\end{array}$} & \multirow{2}{*}{$\begin{array}{c}\text { Photosynthetic } \\
\text { rate }\left(\begin{array}{c}\boldsymbol{\mu} \text { mol } \mathbf{~ m}^{-2} \\
\left.\mathbf{s}^{-1}\right)\end{array}\right. \\
8.49\end{array}$} & \multirow{2}{*}{$\begin{array}{c}\text { Transpiration } \\
\text { rate } \\
\begin{array}{c}\left.\mathbf{m}^{-\mathbf{2}} \mathbf{s}^{-\mathbf{1}}\right) \\
2.88\end{array}\end{array}$} & \multirow{2}{*}{$\begin{array}{c}\begin{array}{c}\text { Anthocyanin } \\
\text { content (mg }\end{array} \\
\text { 100g }^{-1} \text { tissue) }\end{array}$} \\
\hline $\mathbf{G}_{1}$ & $\begin{array}{l}\text { Heliconia cv. } \\
\text { Golden Torch }\end{array}$ & & & & & \\
\hline $\mathbf{G}_{2}$ & $\begin{array}{l}\text { Heliconia } \\
\text { psittacorum rubra }\end{array}$ & 30.00 & 0.12 & 2.00 & 0.55 & 2.64 \\
\hline $\mathbf{G}_{3}$ & Heliconia densiflora & 30.60 & 0.04 & 0.81 & 0.45 & 0.00 \\
\hline $\mathbf{G}_{4}$ & $\begin{array}{l}\text { Heliconia cv. } \\
\text { Orange By Gyro }\end{array}$ & 30.40 & 0.14 & 3.72 & 1.79 & 0.00 \\
\hline $\mathbf{G}_{5}$ & $\begin{array}{l}\text { Heliconia cv. Alan } \\
\text { Carle }\end{array}$ & 45.80 & 0.19 & 7.15 & 2.43 & 1.77 \\
\hline $\mathbf{G}_{6}$ & Heliconia rostrata & 38.80 & 0.38 & 9.23 & 4.17 & 3.64 \\
\hline $\mathbf{G}_{7}$ & $\begin{array}{l}\text { Heliconia cv. Eden } \\
\text { Pink }\end{array}$ & 29.60 & 0.21 & 5.39 & 3.10 & 2.69 \\
\hline $\mathbf{G}_{8}$ & Local Check & 31.26 & 0.18 & 4.26 & 2.69 & 0.00 \\
\hline & SEM \pm & 1.93 & 0.05 & 1.38 & 0.34 & 0.21 \\
\hline & $\mathrm{CD}(P=0.05)$ & N.S & 0.17 & 4.24 & 1.05 & 0.65 \\
\hline
\end{tabular}

Increased stomatal conductance is an indicator of higher gas exchange capacity of the leaf (Rho et al., 2012). These results are consistent with recent studies that suggest that a greater distribution of diffuse radiation photons improve leaf gas exchange in several protected crops ( $\mathrm{Li}$ et al., 2009). Our results find support from Abreu et al., (2014) that they recorded maximum stomatal conductance in Passiflora 'Aninha' (0.32 \pm $\left.0.05 \mathrm{~mol}\left(\mathrm{H}_{2} \mathrm{O}\right) \mathrm{m}^{-2} \mathrm{~s}^{-1}\right)$ and in Passiflora 'Priscilla' $\left(0.35 \pm 0.18 \mathrm{~mol}\left(\mathrm{H}_{2} \mathrm{O}\right) \mathrm{m}^{-2} \mathrm{~s}^{-1}\right)$. Among 3 ornamental flowers, under 50 per cent shade net conditions, Pires et al., (2011) found maximum stomatal conductance $(0.30$ $\left.\pm 0.02 \mathrm{~mol}\left(\mathrm{H}_{2} \mathrm{O}\right) \mathrm{m}^{-2} \mathrm{~s}^{-1}\right)$ in Passiflora palmeri var. sublanceolata. Similar opinion was put forwarded by Koniarski and Matysiak (2013) in rhododendron cultivars.

\section{Rate of photosynthesis $\left(\mu \mathrm{mol} \mathrm{m} \mathrm{m}^{-2} \mathrm{~s}^{-1}\right)$}

The data in Table 2 conformed that photosynthetic rate was significantly influenced by various genotypes evaluated. Significantly maximum photosynthetic rate of $9.23 \mu \mathrm{mol} \mathrm{m} \mathrm{m}^{-2} \mathrm{~s}^{-1}$ was recorded in $\mathrm{G}_{6}$ which

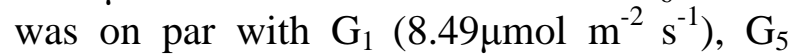

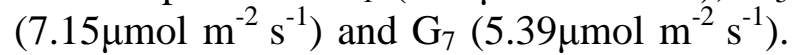
The photosynthetic rate was lowest in $\mathrm{G}_{3}$ $\left(0.81 \mu \mathrm{mol} \mathrm{m} \mathrm{m}^{-2} \mathrm{~s}^{-1}\right)$. More number of suckers results in more production of leaves, the size of the leaf and number of leaves plant ${ }^{-1}$ decides the efficiency of photosynthesis activity which contributed towards better growth and yield. In the present study, heliconia plants under low light intensity were taller, indicating that plants under low light intensity may allocate more biomass to the shoot for the growth of leaves and for the full absorption of limited energy to meet the demand for plant photosynthesis (Walters and Reich, 1999). The increased leaf area of heliconia species under shadehouse condition indicates that plants increase their photosynthetic surface to contribute to a more efficient absorption of light radiation. Fifty per cent shade levels recorded higher plant 
height, number of leaves and petiole length. This phenomenon is consistent with our earlier results corresponding to biometric observations including leaf area. The superior performance level was because of higher leaf chlorophyll content and photosynthetic rate (Gaurav et al., 2015). Under 50 per cent shade net conditions, among 3 ornamental flowers, higher photosynthetic rate $(21.09 \pm 0.60 \mathrm{~m}$ $\left.\mathrm{mol}\left(\mathrm{CO}_{2}\right) \mathrm{m}^{-2} \mathrm{~s}^{-1}\right)$ was recorded in Passiflora morifolia (Pires et al., 2011). The maintenance of photosynthesis in shaded plants compared with exposed trees indicated that use of screen structures in semiarid environments could help reduce plant water stress and increase water use efficiency (Barradas et al., 2005). The increase in diffuse light in greenhouses or tunnels has been noted in other studies, indicating that the polyethylene used promotes a greater transformation of direct light into diffuse light, which results beneficial for photosynthesis and productivity in horticultural crops (Li et al., 2009).

\section{Transpiration rate $\left(\mathrm{mmol} \mathrm{m} \mathrm{m}^{-2} \mathrm{~s}^{-1}\right)$}

A close sight of the data revealed that the genotypes demonstrated highly significant differences for transpiration rate and data is represented in Table 2. Transpiration rate recorded was highest in $\mathrm{G}_{6}(4.17 \mathrm{mmol}$ $\mathrm{m}^{-2} \mathrm{~s}^{-1}$ ) which was found to be significantly superior to all other genotypes which was followed by genotype $\mathrm{G}_{7}\left(3.10 \mathrm{mmol} \mathrm{m} \mathrm{m}^{-2} \mathrm{~s}^{-1}\right)$. In chrysanthemum Aliniaeifard and Meeteren (2016) reported similar type of finding for rate of transpiration $\left(4.95 \mathrm{mmol} \mathrm{m}^{-2} \mathrm{~s}^{-1}\right)$. Pires et al., (2011) also recorded maximum transpiration rate in Passiflora palmeri var. sublanceolata $\left(5.09 \pm 0.20 \mathrm{mmol}\left(\mathrm{H}_{2} \mathrm{O}\right) \mathrm{m}^{-2} \mathrm{~s}^{-1}\right)$ among 3 types of ornamental passion flowers. Our results coincide and get support from the above authors findings. The rate of transpiration was found to be inversely proportional to shade level. Transpiration rate is directly dependent on temperature, light intensity, relative humidity and transmittance. Moderate shading levels resulted in reduced leaf temperature and leaf transpiration without reducing net photosynthesis. This reduced leaf transpiration was likely attributed to reduced evaporative demand and probably explains the increased soil water content and reduced plant water uptake under shaded conditions. The linear relationship between net photosynthesis and stomatal conductance suggests that stomatal control of photosynthesis was substantial under shade. The increased internal $\mathrm{CO}_{2}$ concentration with increased shade level also suggests, however, that there were also non-stomatal factors such as mesophyll or biochemical factors, limiting net photosynthesis (Assmann, 1992).

\section{Anthocyanin content in flowers (mg $10 \mathrm{~g}^{-1}$ tissue)}

The data depicted for this attribute is made available in Table 2 and heliconia genotypes differed significantly for the attribute tested. Among the genotypes studied, the genotype $\mathrm{G}_{6}$ produced the highest anthocyanin content (3.64 mg $100 \mathrm{~g}^{-1}$ ) which was found significantly superior over all other genotypes which was followed by $\mathrm{G}_{7}\left(2.69 \mathrm{mg} 100 \mathrm{~g}^{-1}\right)$. The remaining genotypes viz., $\mathrm{G}_{3}, \mathrm{G}_{4}$ and $\mathrm{G}_{8}$ did not show anthocyanin content as they do not come for blooming during the period of study. The presence of anthocyanin and carotenoid pigments colouration have been demonstrated in the inflorescence bracts of other ornamental rhizomatic plants like heliconia (Mangave, 2010) and bird-ofparadise (Pirone et al., 2010). In addition, Tatsuzawa et al., (2010) reported that both anthocyanins and carotenoids significantly influenced the flower colour in different cultivars of orchids that resulted in orange-red and red flowers. Our result showed that the increase in anthocyanin contents was affected the photosynthetic pigment accumulation in 
the bracts during early pigmentation. These observations indicate that photosynthetic pigments were synthesized in the first stage of inflorescence development before replaced by the different phenolic compounds. The observation is in agreement with the finding of Slatnar et al., (2013) in poinsettia inflorescence bracts. Shading treatments were significantly affected the pigmentation patterns and inflorescence development of heliconia. The results are corroborated with the findings in bougainvillea (Saifuddin et al., 2010), petunia (Albert et al., 2009) and daisy (Meng et al., 2004).

Finally, it may be concluded that, Heliconia rostrata $\left(\mathrm{G}_{6}\right)$ was proved to be the best among the other heliconia genotypes for enhanced growth, flowering, physiological, biochemical and yield parameters. Hence it may be suitable for commercial cultivation under shadehouse conditions in Rayalaseema region of Andhra Pradesh.

\section{Acknowledgements}

This paper forms the part of the M. Sc (Horticulture) Thesis in Dept. of Floriculture \& Landscape Architecture of the first author submitted to Dr. Y.S.R Horticultural University, Venkataramannagudem, Andhra Pradesh, India.

\section{References}

Abreu, P.P.S., Almeida, M.M., Santos, A.F., Freitas, J.C.O. and Figueiredo, A.L. 2014. Photosynthetic response of ornamental passion flower hybrids to varying light intensities. Acta Physiol Plant. DOI 10.1007/s11738-014-1574.

Albert, N.W., Lewis, D.H., Zhang, H., Irving, L.J., Jameson, P.E. and Davies, K.M. 2009. Light-induced vegetative anthocyanin pigmentation in petunia. Journal of Experimental Botany. 60(7):
2191-202.

Aliniaeifard, S. and Meeteren, U.V. 2016. Stomatal characteristics and desiccation response of leaves of cut chrysanthemum (Chrysanthemum morifolium) flowers grown at high air humidty. Scentia Horticulturae. 205: 84-89.

Assmann, S.M. 1992. Effects of light quantity and quality during development on the morphology and stomata physiology of Commelina communis. Oecologia. 92: 188-195.

Aundhakar, P.R. 2008. Effect of nitrogen and potash on growth, flowering, yield and quality of Heliconia cv. Golden Torch under shade house. M.Sc. (Hort) Thesis. Dr. Balasaheb Sawant Konkan Krishi Vidyapeeth, Dapaoli, India.

Balaram, M.V., Janakiram, T. and Vasantha, K.E. 2009. Performance of Indian and exotic gladiolus genotypes. Journal of Ornamental Horticulture. 12: 95-100.

Barradas, V.L., Nicolas, E., Torrecillas, A. and Alarcon, J.J. 2005. Transpiration and canopy conductance in young apricot (Prunus armenica L.) trees subjected to different PAR levels and water stress. Agricultural Water Management. 77: 323-333.

Chen, J.M., Liu, J., Cihlar, J. and Goulden, M.L. 1999. Daily canopy photosynthesis model through temporal and spatial scaling for remote sensing applications. Ecological Modeling. 124:99-119.

Dalawai, B., Mantur, S.M. and Biradar, M.S. 2017. Performance of Heliconia genotypes for vegetative and flowering traits under shadehouse condition. Journal of Pharmacognosy and Phytochemistry. 6(6): 2023-2025.

De Groot, C.C., Marcelis, L.F.M., van den Boogaard, R. and Lambers, H. 2002. Interactive effects of nitrogen and irradiance on growth and partitioning of 
dry mass and nitrogen in young tomato plants. Functional Plant Biology. 29: 1319-28.

Fanourakis, D., Carvalho, S.M.P., Almeida, D.P.F. and Heuvelink, E. 2013. A comprehensive analysis of the physiological and anatomical components involved in higher water loss rates after leaf development at high humidity. Journal of Plant Physiology. 170: 890-98.

Gaurav, A.K., Raju, D.V.S., Janakiram, T., Singh, B., Jain, R. and Krishnan, S.G. 2015. Effect of shade levels on production and quality of cordyline (Cordyline terminalis). Indian Journal of Agricultural Sciences. 85(7): 931-35.

Juan, C.D. 2013. Bell Pepper (Capsicum annum L.) crop as affected by shade level: Microenvironment, plant growth, leaf gas exchange and leaf mineral nutrient concentration. Hort Science. 48(2): 175-82.

Kadam, D.S., Sheela, V.L. and Narkar, N.D. 2011. Variability studies in seedlings of Heliconia (Heliconia spp.). Journal of Ornamental Horticulture. $15(1 \& 2)$ : 5357.

Kokila, K.R., Satheeshan, K.N., Rajagopalan, A., Giridharan, M.P. and Rao, G.V.S. 2016. Regulation of Growth and Flowering in Heliconia spp. M. Sc Thesis, Kerala Agricultural University, Kerala, India.

Koniarski, M. and Matysiak, B. 2013. Growth and development of potted rhododendron cultivars 'Catawbiense Boursault' and 'Old Port' in response to regulated deficit irrigation. Journal of Horticultural Research. 21(1): 29-37.

Lewis, D.A. and Nobel, P.S. 1977. Thermal energy exchange model and water loss of a barrel cactus, Ferocactus acanthodes. Plant Physiology. 60: 609616.

Li, S.H., Genard, M., Bussi, C., Huguet, J.G.,
Habib, R., Besset, J. and Laurent, R. 2009. Fruit quality and leaf photosynthesis in response to microenvironment modification around individual fruit by covering the fruit with plastic in nectarine and peach trees. Journal of Horticultural Science and Biotechnology. 76(1): 61-69.

Lykas, C.H. and Katsoulas, N. 2012. Use of shading nets to improve quality characteristics of compact gardenia (Gardenia jasminoides Ellis) potted plant. Acta Horticulturae. 952: 281285.

Malakar, M., Acharyya, P. and Biswas, S. 2015. Evaluation of heliconia Species based on agro-morphological Traits. International Journal of Agriculture, Environment and Biotechnology. 8(4): 957-964.

Mangave, B.D. 2010. Postharvest physiology and quality of heliconia inflorescence cv. Golden Torch as influenced by antioxidents. M.Sc. Thesis. Navsari Agriculture University, Navsari, India.

Meng, X., Xing, T. and Wang, X. 2004. The role of light in the regulation of anthocyanin accumulation in Gerbera hybrida. Plant Growth Regulators. 44: 243-250.

Panse, V.G. and Sukhatme, P.V. 1978. Statistical methods for agricultural workers. Indian Council of Agricultural Research, New Delhi.

Pirone, C., Jodie, V.J., Martin, J. and Quirke, E. 2010. The animal pigment bilirubin identified in Strelitzia reginae, the bird of paradise flower. HortScience. 45(9): 1411-15.

Pragya, Ranjan, J.K., Attri, B.L., Das, B., Krishna, H. and Ahmed, N. 2010. Performance of gladiolus genotypes for cut flower and corm production under high altitude of Uttarakhand. Indian Journal Horticulture. 67: 386-390.

Rho, H., Yu, J.D., Kim, S.J. and Lee, J.H. 
2012. Limitation factors for photosynthesis in 'Bluecrop' highbush blueberry (Vaccinium corymbosum) leaves in response to moderate water stress. Journal of Plant Biology. 55: 450-457.

Saifuddin, M., Hossain, A.M.B.S. and Normaniza, O. 2010. Impacts of shading on flower formation and longevity, leaf chlorophyll and growth of Bougainville glabra. Asian Journal of Plant Sciences. 8:1-8.

Saleem, M., Ahmad, I. and Khan, M.A. 2013. Cultivar Effects on Growth, Yield and Cormel Production of Gladiolus (Gladiolus grandiflorus L.). Journal of Ornamental and Horticultural Plants. 3: 39-48.

Sheela, V. L., Sabina George, T., Rakhi, R. and Geethalekshmi, P. R. 2007. Variability studies in cut flower varieties of Heliconias. Indian Journal of Horticulture. 64(1): 109-111.

Sirisha, B. 2016. Morpho-physiological and biochemical responses of gladiolus cv. Arka Amar to plant growth regulators and arbuscular mycorrhizal fungi (AMF). M.Sc (Hort.) Thesis, Dr. Y.S.R. Horticultural University, Andhra Pradesh.

Skelton, R.P., Midgley, J.J., Nyaga, J.M.,
Johnson, S.D. and Cramer, M.D. 2012. Is leaf pubescence of Cape Proteaceae a xeromorphic or radiation protective trait. Australian Journal of Botany. 60: 104-13.

Slatnar, A., Maja, M., Veberic, R., Stampar, F. and Schmitzer, V. 2013. Anthocyanin and chlorophyll content during poinsettia bract development. Scientia Horticulture. 150(4): 142-145.

Tarannum, M.S. and Naik, H.B. 2014. Correlation studies in carnation (Dianthus caryophyllus L.). Journal of Horticultural Sciences. 9(1): 38-42.

Tatsuzawa, F., Ichihara, K., Shinoda, K. and Miyoshi, K. 2010. Flower colours and pigments in Disa hybrid (Orchidaceae). South African Journal of Botany. 76(1): 49-53.

Walters, M.B. and Reich, P.B. 1999. Lowlight carbon balance and shade tolerance in the seedlings of woody plants: do winter deciduous and broadleaved evergreen species differ? New Phytologist. 143(1): 143-54.

Wang, Q., Chen, J., Stamps, R.H. and Li, Y. 2005. Correlation of visual quality grading and SPAD reading of greenleaved foliage plants. Journal of Plant Nutrition. 28: 1215-25.

\section{How to cite this article:}

Dilipkumar Naik, M., M. Raja Naik, M. Ramakrishna, K. Lalitha, K. Arunodhayam and Sharat Kumar Reddy, Y. 2019. Multiple Heliconia Genotypes under 50 Per Cent Shadehouse Conditions: Physiological and Biochemical Responses. Int.J.Curr.Microbiol.App.Sci. 8(08): 220-229. doi: https://doi.org/10.20546/ijcmas.2019.808.026 